\title{
Breaking through the Institutional Barriers of Private Capital Entering Urban Public Utilities
}

\author{
Sun YanHua* \\ College of Finance and Public Management \\ Harbin University of Commerce \\ Harbin, China \\ jenna2002039@126.com
}

\author{
Li Erbin \\ College of Economic and Management \\ Northeast Forestry University \\ Harbin, China \\ li_erbin@126.com
}

\begin{abstract}
Urban public utilities are the carrier and the foundation of economic and social development, its development level and the rate of development directly relate to urban economic development and overall social progress. Longterm single government investment has caused various disadvantages such as out-dated management system and low operating efficiency, so it is imperative to absorb private capital and competition mechanism into urban public utilities. A series of institutional barriers due to the imperfections of the system, that is traditional institutional barriers, administrative monopolistic barriers, credit and financing barriers and so on, impeded private capital to enter urban public utilities greatly and reduced the enthusiasm of private enterprises in the construction of urban public utilities significantly. To break through these institutional barriers, the government should perfect the policies and regulations to protect legitimate interests of private capital to participate in the construction of urban public utilities; and speed up the separation to transform governmental functions; and innovate financing system to widen the financing channels and modes and set up the Government's credit to enhance private investor's confidence.
\end{abstract}

Keywords-Private capital; urban public utilities; institutional barriers; administrative monopoly

\section{INTRODUCTION}

Urban public utilities mean various public service careers, including supplies of water, gas, heat and electricity, as well as sewage treatment, garbage disposal, public transportation (exclusive of air aviation and railway)and landscaping, environmental protection, etc. Urban public utilities are the carrier of urban economy and social development; they directly concern social public interest, quality of people's life and the sustainable development of urban economy and society. Accelerating development of urban public utilities is an important measure for the perfection of urban function and promotion of urban development; it is also the essential contents for meeting requirements of basic life of city residents and constructing well-off society in an all-around way. Because urban public utilities has basic, monopoly, external and public spirited characteristics, urban public utilities in our country implement the management system of monopoly of state-owned enterprises for a long time.But with the development of social

\footnotetext{
* Corresponding author
}

economy and urban public utilities, deepening reform of national economic system, the multiple defects of the management system including low operating efficiency of the system, lack of competition vigor and single investment channels caused serious shortage of investment are more and more obvious, these provide a great opportunity for private capital to enter the urban public utilities. Since 1990s, increasingly definite policy orientation is to encourage private enterprises to enter the urban public utilities; the State Council, China promulgated The Views on Encouraging and Guiding the Healthy Development of Private Investment ("New item 36"). Especially in 2010, China put forward to support private enterprises to enter urban public utilities more clearly.Private enterprises in China kept high-speed, continuous, comprehensive growth since the 1990s. The development speed of private enterprises has exceeded other economic components greatly, and they have certain strengths to try to enter urban public utilities.

Private capital participation has great significance for the construction of urban public utilities. Firstly, it is beneficial to alleviate the huge pressure from the insufficient urban capital and the financial burden of the Government. Secondly, the introduction of the participation of private capital can improve the efficiency of investment. Through the involvement of private capital to introduce competition and price mechanism, which promote construction and operational efficiency of urban public utilities. Thirdly, attracting private capital into the field of urban public utilities construction, introducing competition mechanism, regulating market operations, that will help break the longstanding monopoly and improve the service quality of urban public utilities construction.Private capital participation is the behavior of competition with governmental capital, its purpose is to obtain scarce resources-public utilities' ownership or management rights [1]. However, some private enterprises can enter the urban public utilities and obtain the scarce resources, whereas the other private enterprises are unable to achieve the purposes. Such differences exist objectively, which may be caused by institutional barriers.

\section{BODY}

\section{A. Institutional Barriers of Private Capital Entering Urban Public Utilities}

Institutional barriers refer to the access barriers of the government policies, laws, and other factors for social system. According to the theory of internal systems and external institutions, institutional barriers to entry include both industrial external control legislation and institutional barriers outside industrial policy, including industrial intrinsic values, selfmanagement mechanism construction and social identity of value 
The First International Symposium on Business Cooperation and Development in South-East and South Asia under B\&R Initiative (ISBCD-16)

degree, fair competition idea of enterprise of internal system barriers. Both work together to build the institutional barriers to entering the industry.

China is being at a transitional stage, private capital entering urban public utilities will encounter institutional barriers due to the imperfections of the system. These barriers are not beneficial for rapid development of urban public utilities, and at the same time they will also impede progress on utilities reform.

\section{1) Traditional Institutional Barriers}

The private capital cannot blend in urban public utilities substantially for a long time, which has become serious obstacles to develop private enterprises. In 2005, the State Council issued The Views on Encouraging, Supporting and Guiding Private Development of Non-public Ownership Economy ("Item 36"). It clearly proposed "allowing non-public capital into the monopoly industry and areas such as power, telecommunications, railways, speed up reforms to introduce market competition mechanism". Although "Item 36" has proposed to lower the barriers of private enterprises entering monopoly areas, many resistances occur in the process of implementation [2]. The Governmental performance also has a problem because of inadequate institutional support files on the one hand, personalities of various circles are more or less discriminatory on small and medium enterprises on the other hand. The State Council promulgated "New item 36". With respect to "Item 36", market access problems faced by private capital are no longer the high voltage line of the Government in many areas, that is not to allow private capital entering, but the emergence of the"spring-loaded door" [3]. Because the various aspects of the reform could not keep up with in some industries, private enterprises entered these industries at the initial stage, but they would be eliminated due to the competition in the end. The Views on deepening Economic System Reform was promulgated in 2009.National development and Reform Commission, the Ministry and other departments should research related policies on the private capital entering railway, petroleum, electric power, telecommunications, municipal utilities and other important areas to stimulate social investment. However, because the electricity and water price is always monopolized by state in China, state-owned water supply and heating enterprises got price compensation for a long-term. The compensation mechanism rejected the entry of private capital greatly, and led to private capital still in inferior position in the competition.

\section{2) Administrative Monopolistic Barriers}

Currently there is a high administrative monopoly in managing urban public utilities. State-owned economic sector occupy a dominant position, the Government as the owner almost control the entire industry. The Government can limit the private capital to enter certain areas by means of Legal and administrative means, and limit the investment scale of private capital through tax means, and consolidate monopoly selfdecision and usu fruct through controlling interest on private capital. Some areas have been introduced a considerable degree of competition, but still retain its administrative monopoly. The entry barrier to administrative monopoly makes industry in low running efficiency [4]. On the one hand, governments are not only business owner but also community manager in the transitional period. This makes that the government still intervenes market in many ways and activity of enterprise entering the market freely. On the other hand, though various economic activities on the market activity have been regulated by legal, it mainly depends on administrative mechanism to supervise and punish. At the same time based on Angle of each administrative department is not the same, and administrative C 2016. The authors - Published by Atlantis Press. regulations on the same economic behavior is not the same. So supervision and punishment on the specific economic activities will primarily depend on the administrative departments in charge of the intention. In addition, administrative monopoly is very easy to breed corruption. Administrative monopoly is the product of the combination of market corruption and political corruption. First, administrative monopoly is the indistinction between the functions of the results, and strengthen the indistinction between the functions of the catalyst; secondly, administrative monopoly in essence is a kind of bartering and birthplace of new bartering. In a word, administrative monopoly of rate of return and administrative monopoly of flooding degree were with the corrupt behavior occurred there is a certain positive correlation.

\section{3) Credit Barriers}

Current laws and regulations to regulate the behavior of operators to stop administrative monopoly and unfair competition, protection of investor enthusiasm and reasonable returns and restrain government's administrative intervention is still not perfect and specific. The range on investment in privatization of urban public utilities, the privatization methods and procedures are not clear enough, and mostly of the Department are in charge of construction rules and local government policy documents, which legal effect is low, and private enterprices worried the government flip-flop, dishonesty, that investment income is not guaranteed. For example, in the need for government subsidies or tax return of the industry, some companies are facing the government's commitment can not be fulfilled, some of the payments in arrears and other issues, some industries are also facing a variety of acts of unfair competition and so on.

Some local governments only consider the investment problems and provide a higher return on investment on the private enterprises in order to absorb private enterprises into urban public utilities. But under the pressure of price controls and the general community, it is difficult to achieve commitments so as to result in lack of commitment of the Government. Therefore, frequent lack of government commitment events occurring on private enterprises to enter the urban public utilities formed an investment risk, hindering private enterprise to enter urban public utilities. The largest sewage treatment plant shut down in Changchun city in February 2004, 390,000 tons of sewage drained off into Songhua River straightly. The cause was that the factory (foreign) did not receive discharge fee but cannot maintain the operation. And Changchun Municipal Government believes that the last contract content belonged to a fixed rate of return in disguise, it should be terminated such as fixed sewage treatment base number, base price, fixed dollar and RMB exchange rate [5]. In addition, the government policy changes frequently which not only hurt the government's image in the public mind but also increase the enterprise investment risk, and contuse the enterprise investment interest.

\section{4) Financing Barriers}

Operation of urban public utilities requires large up-front costs of inputs, and these inputs can not be transferred to other uses easily, thus it would form a huge sunk cost. For example, the Shanghai water sold 50\% property rights and operation rights to private enterprises in the franchise and property sale mode, its overall transfer fees were 2.026 billion yuan. Shenyang Water was another example to obtain funding in this way. Private enterprises need pay 0.125 billion yuan and $5.4 \%$ of the rental rate every year in the property rights transfer process. In the face of such a huge amount of capital investment, the majority of private enterprises were limited because of funding, financing 
The First International Symposium on Business Cooperation and Development in South-East and South Asia under B\&R Initiative (ISBCD-16)

ability and only steped back. In addition, after private enterprises obtained property or right of administration of urban public utilities, and still increased investment in order to improve urban public facilities, and assumed operation cost of urban public utilities.

Although some attentions have been paid to the status and role of folk capital in the construction of urban infrastructure in China, financing channels and means are one-dimensional at present [6]. And credit financing is still the main source of funds. Because of the national policy's constraints, the bias of stateowned commercial banks, high loan interest rates, credit problems of private enterprise and so on, loan quantity and scale of private enterprises are restricted by state-owned commercial banks, even less than 1. This greatly influences private enterprises' enthusiasm about investment on urban public utilities, and obstacle development of the enterprise seriously.

\section{5) Price Barriers}

Prices of urban public utilities in our country under the traditional regulatory conditions is lower in a long term. After the reform and opening up, some adjustments were happened, but the prices can not get to make up the cost of business, and there has been widespread policy-related losses. After private capital into the urban public utilities, in order to maintain the normal operation of the enterprise and reap profit, it will require that the price adjustment is in fact the price increase[7]. Since it is a price increase, there is a degree of price increases, consumers can not afford if the price increases are too much, private capital is not willing to enter if the price increases are small. At present, pricing of urban public utilities in our country is based on "Price Law of the People's Republic of China"(the"Price Law"), and the mechanism of setting the price is the national price department, but content of the "Price Law"contained a wide range, which only provides on general principles in utility pricing, and does not account the coordination of producers, consumers and the Government in the pricing, and does not clearly define business costs and how to determine a reasonable profit margin. So it is lack of operational characteristics in real life and specific provisions of pricing and price in urban public utilities, only the specific industry, the product of a detailed analysis, but there is no uniform procedures and regulations.

\section{B. Breaking through the Institutional Barriers of Private Capital Entering Urban Public Utilities}

\section{1) Perfecting Policies and Regulations}

Ministry of construction issued The Views on Accelerating Process of Marketization of Urban Public Utilities in 2002. Later Central Government, the provinces and cities introduced a series of preferential policies for files and so on. But some provisions were too broad and specific provisions were little, at the same time interoperability was poor[7]. For example, it was put into practice for Urban Public Utilities Franchising Management Measures on May 1, 2004. Although it had a strong guiding significance and constraints on many city and county governments lack of awareness of the franchise, some substantive problems did not set. Such as franchising, scope, under the franchising system of property right, how to compensate the enterprises of voluntary early termination or cancellation of the right, how to balance enterprises' economic interests and the public interests; At the same time, the views was lack of scientific and reasonable scale about regulatory provisions of the content and form. In order to remove obstacles of private capital entering the system of urban public utilities and protect legitimate interests of private capital to participate in the construction of urban public utilities, government should further modify, clean up and revise laws, regulations and policies restricting on the development of private capital according to relevant provisions, and remove institutional barriers[8].

\section{2) Accelerating the Separation}

Integration of government administration with enterprise is a source of administrative monopoly. This Government administrative system of unity of Government and Enterprise offer soil and facilities for administrative monopoly. If do not implement system reform and does not change the relationship between Government and enterprises, it is impossible to separate special interests from enterprises and government relations. It is also impossible to eliminate unreasonable administrative protection and administrative privileges, thus making it impossible to break the administrative monopoly. So it is necessary to accelerate the system reform for realizing the separation of government and enterprises; implementing reconstruction to form the competitive market; implementing privatization reforms to reshape the market main body; exercising effective control to take incentive regulation. Enterprises should become market entity independent of their business after the separation of the market, and expand production and business activities in accordance with the principles of a market economy, in pursuit of maximum profit for the business objectives, and strive to improve efficiency. The separation requires not just stripping out government functions from enterprise, but asking the Government to further separation of functions. That is the separation of three functions as regulation, regulators and State-owned assets of the Government. The Government should set up the appropriate regulatory body and exercise regulatory function independently, and implement, supervise the implementation of enacted policies in the supreme interests of the State as a criterion.

\section{3) Innovating Financing System}

As the increase in the speed and scale of the development of private enterprise in China, it will be gradually easing of restrictions on private enterprise, particularly investment in lagging public utility industries. Major obstacles influencing the financing of private enterprises come from the bias of the Stateowned commercial banks and private enterprise's credit. The private enterprises may enhance their credits to win over commercial bank loans through improving the level of enterprise management, strengthening enterprise's credit management, perfecting the enterprise's credit evaluation system, strengthening financial institutions for confidence in public private enterprises. In addition, in order to guarantee public private enterprise to obtain funds smoothly, local governments may provide credit guarantees to enhance its credit ratings. Except lending to State-owned banks, private enterprises can also seek help to private financial institutions. Private financial institutions arise from dredging the financing channel of private enterprises, and they have irreplaceable advantages in Stateowned commercial bank, such as low transaction and low rent seeking cost advantage,high efficiency and strong adaptability advantage to market. At the same time, governments should actively guide and support the private investors to raise money through the issuance of bonds, stock, and dredge the channel of entry and exit.

\section{4) Setingt up the Government's Credit}

Construction investment on urban public utilities is, in fact, an established cooperative relationship with governments. Government must be based on their good faith to uphold private capital input.According to the present requirements of administrative licensing law, the Government cannot arbitrarily 
The First International Symposium on Business Cooperation and Development in South-East and South Asia under B\&R Initiative (ISBCD-16)

revoke administrative licensing. But some of our Governments have lost their integrity. Government terminated the contract according to the contract agreement before the private enterprises have performed the contract. This not only affected urban public utilities construction, but also lost Government's credibility in the minds of investors. Government upholds honesty through formulating appropriate return on investment on urban public utilities. Because the return on investment is the most comprehensive and direct reflection on project return on investment, and thus it is one of the most concern issues for various investors including private entrepreneurs. Private capital investing in urban public utilities simply is its profitable. If not a certain return on investment, private enterprises will not invest in urban public utilities actively and effectively.And the Government can control return on investment by means of macroeconomic regulation. The Government may regulate by means of adjusting service prices and so on, if private investors cannot recover its investment or acquisition profiteering due to objective economic conditions occurred larger changes, and affects the return on their investment, encourages or inhibits the expansion of private capital on the basic industry.

\section{5) Establishing an Effective Price supervision system}

Pricing principle is fundamental, several major pricing principle in "Price Law" has still significance in the postprivatization.Pricing principles include the following: guaranteeing the normal production of the operators after private capital into urban public utilities to obtain a reasonable profit. Only to get a reasonable profit can attract all kinds of capital into urban public utilities, and enterprises are able to cover costs from the normal production and business activities, and enterprises will have enough profit into the production, which is conducive to maintaining a positive and improvement of productive scale and efficiency, promote the development of privatization. To give a reasonable burden on consumers, the development of prices should fully reflect consumption costs depending on the characteristics of different industry and taking into account a reasonable extent of the burden of different groups and reflecting differences in the consumption characteristics of consumer but also actively promoting consumption; Guaranteeing the sustainable development of social economy, consumption of resources in urban public utilities is huge, and its cost is enormous, so production should as far as possible maintain balance between supply and demand, and avoid structural imbalances in the form of a great waste of social resources. Through the price regulation of urban public utilities makes it is consistent for the price of public goods and social development, and has a positive role in promoting the development of economy; Pricing should take account of the interests of vulnerable groups and take into account the social welfare, the principle has a very important significance to maintain social stability and promote the harmonious development of society and is an important factor in pricing.

The pricing subject of urban public utilities in "Price Law" is the national price department and after the privatization of public utilities. The pricing subject should be a composite body integrated interests of all parties rather than just the national price department. The pricing composite body should include representatives of government, business and the general public and other related aspects. The advantages of complex decisionmaking is to change the unfavorable situation of the information, technology and personnel and other aspects of pricing department,and synthesize views of all parties and develop social resources effectively, and develop the reasonable prices of public goods, and reduce conflict and alleviate pressure for reform.At the same time, because the interests parties in the complex decision-making restrain and restrict each other, this forms a restraint and supervision over the pricing largely which to avoid the capture of government to some extent.

\section{CONCLUSION}

In recent years, the management scale of the private enterprise have been expanded constantly, and economic strength has been enhanced obviously in recent years in China. They have accumulated a considerable potential for social investment, and need to open up new avenues of investment. So some private enterprises put money into urban public utilities. Most of the private enterprises also wish to obtain profits in novel fields. The government should clear the existence institutional obstacles timely to the private enterprises to become more involved in the construction of urban public utilities, to overcome the drawbacks of single government investment, provide a higher quality of urban residents, more cost-utility products .

\section{ACKNOWLEDGEMENT}

We thank Chen Ming, Cui Guoqing, Wang junhao, $\mathrm{Hu}$ Xiuzhu, Jing Lina, Li Guizhi, PENG,M., Xi Shujiang, Zhou Xiaomei and Zhang Huiheng for their help in urban public utilities and privatization.Comments from Drs. Liu ping,Wang Shuguang, and two anonymous reviewers significantly improved this manuscript.This essay was financially supported by Humanities and Social Sciences Project of Heilongjiang Provincial Education Department (12542057).

\section{REFERENCES}

[1] M. Chen, "Policy Dilemma of Privatization of Urban Public Utilities-With Water Private into An Example," Contemporary Finance \& Economics, pp. 18-20, December 2004.

[2] G.Q. Cui, "Asset Securitization and Investment and Financing Innovation of Urban Infrastructure," Operation \& Management, pp. 25, August 2008.

[3] J.J. Gong, and J.H. Wang, "A Study on Entrepreneurship and the Barriers to the Entry into the City-Owned Utilities," Economist, pp. 35-39, November 2011.

[4] X.Z. Hu, "Institutional Barriers of Private Economy to Entry into the Gas Industry in China," Journal of Fuzhou University (Philosophy and Social Sciences), pp. 85-86, February 2009.

[5] L.N. Jing, and Z.H. Ma, "Research on the Ant-Adm Inistrative Monopoly and Promoting Competition of Natural Monopoly Industry," Journal of Hebei University of Technology (Social Sciences Edition), pp. 37-39, October 2010.

[6] G.Z. Li,and G.G. Li, "Improve System Environment of Private Capital into the City Infrastructure Construction," Industrial \& Science Tribune, pp. 1920, January 2007.

[7] M.W. Peng, and Y.D. Luo, "Managerial Ties and Firm Performance in a Transition Economy:The Nature of a Micro-macro Link," Academy of Management Journal, vol. 43, 2000, pp. 486-501.

[8] S.J. Xi, "The Theoretical Basis, Current Problems and Development Path of Private Capital into the Energy Industry," Special Zone Economy, pp. 143, December 2009.

[9] X.M. Zhou, "Effects and Problems of Privatization of Urban Public Utilities in China," Modernization of Management, pp. 54-55, June 2011.

[10] H.H. Zhang, "Obstacles and Breakthrough of Non-public Ownership Economy into Public Utilities,” Economic Affairs, pp. 34-37, June 2009. 